\title{
RÉQUIEM PARA PORTUGAL
}

\section{Antonio Marcos Gonçalves Pimentel ${ }^{1}$}

$\mathrm{Na}$ parede da suntuosa biblioteca, pendia uma enorme tapeçaria com um exuberante mapa-múndi. Obra de arte inigualável, que dava ares de requinte ao ambiente com suas geografias meio âmbar meio pastel, um toque clássico, que compunha um conjunto de sobriedade e erudição junto com a lareira abaixo de si, onde crepitavam pequenas porém vigorosas e teimosas labaredas, e de onde se ouvia o espocar da lenha seca. Murmúrios de livros e de passados. Era inverno, e Portugal sofria com uma rigorosa onde de frio, mais gelada do que o normal: branca Serra da Estrela.

Um pouco à frente da lareira, bem espaçados um do outro, dois bustos em bronze, erguidos no ar por duas lindíssimas colunas de marfim, estilo dórico. Passados imaginados do outro lado do continente. As figuras esculpidas entreolhavam-se do alto de seus quase dois metros. Camões e D. Sebastião: uma austeridade tumular, imobilidade de um silêncio incômodo. Sussurros passados: entendimentos. Diálogos.

Às suas costas, estantes de livros que cobriam ambas as paredes, altas, altíssimas; largas, larguíssimas, por onde percorriam ávidas de História as sombras dos dois distintos portugueses manipuladas pelo fogo da lareira. Deuses Lares, algozes de Viriato. Nas estantes, uma infinidade borgiana de livros; disposição milimétrica dos tomos perfeitos, mesmo em sua quase desintegração. Passados irrecuperáveis. Podia-se chegar aos volumes mais ao alto subindo-se pelas duas longas e modernas escadas de aço, que reluziam e refletiam o fogo perene da lareira. Uma atmosfera de penumbra pincelava o quadro da biblioteca: sépia, como imagens do passado. No centro do grande salão, sobre um tapete de motivos árabes - as Mil e Uma Noites -, mesas, poltronas e algumas cadeiras rococó pisoteavam gênios, sultões, garças, pavões e até casais se amando profundamente. Didaticamente. Despretensiosamente.

Do outro lado da sala, em oposição à lareira, duas enormes portas de madeira do pinhal de Leiria selavam o lugar, ladeadas por tapeçarias que retratavam vitórias imaginadas nas Cruzadas. Nos entalhes, navegavam Vasco da Gama e Pedro Álvares de Cabral, cada um singrando os nós das lâminas de pinho com suas respectivas naus: alto-

\footnotetext{
${ }^{1}$ Professor credenciado no departamento de especialização lato sensu em Língua, Literatura e Cultura Latina da UFF (RJ). É mestre em Letras (UFF/RJ) e doutorando em Literatura Comparara (UFF/RJ) e escritor.
} 
relevo, detalhes. Passados táteis: necropsia. No centro da dupla porta de madeira, divido, o brasão do Império Português esculpido com uma paixão quase arrependida, culpada.

No alto do mapa âmbar podia-se ler a inscrição O Quinto Império, urdida de fios claros, destaque sutil no tom escuro do mundo, um mundo que não era o espelho da realidade geopolítica daquele ano de 2016, que um pequeno calendário com imagens da República dos Açores insistia em mostrar, colocado entre os dois candelabros de ouro apoiados sobre o cimo da lareira. Foram-se também os Açores, voaram como o Corvo, pequena ilha, presunçosa, independente, orgulhosa. Portugal, em verde-escuro, fazia par com os outros verdes do continente Africano, da China e do Japão, da América do Sul, de incontáveis ilhas da Oceania e da Índia. Destacado das áreas verdes, em dourado orgulhoso, o brasão português. O que não era fora trançado em verde, não era nada, pois não tinha nome, apenas fronteiras.

O silêncio imponente na biblioteca era quebrado de quando em quando ou pelo estalido das brasas à lareira, mas por um soluçar, um lamento abafado, doído. Choro incontido, contínuo, de uma tranquilidade incompatível com o tamanho da dor que parecia ser sentida, vindo de uma das poltronas mais à esquerda da sala, próxima ao busto de D. Sebastião. Abandonara-se ali um homem jovem, de uns trinta anos talvez. Bem vestido, distinto. No colo pousara-lhe um livro de Fernando Pessoa, fechado, ostentando um marcador de livros despreocupado em marcar uma página em especial. Choro doloroso, choro resignado; inconformado pela própria resignação. O jovem tira os óculos de leitura embaçados de sobre o nariz e deixa-os cair no tapete. Tira com carinho o Pessoa do colo e coloca-o sobre a mesa redonda e baixa à sua frente, acariciando-lhe a capa. Permaneceu ainda por alguns minutos abandonado por si mesmo à poltrona, quando, por fim, o choro cessou, de tanto que implorou o crepitar das chamas.

Os olhos molhados e vermelhos, a fitar as curvas de uma odalisca no tapete, punham-se, agora, para o alto, a mirar o Quinto Império português. Secando a face e os olhos com a manga do paletó caro e antigo, o homem levanta-se de sua pachorra e, com magros passos, dirige-se em direção da utopia cartográfica. Namorou-o por um tempo, como quem namora a jovem à janela, sem pressa, sem tempo. Passa os dedos de leve por sobre a tapeçaria, acaricia as terras em verde, sorri-lhes, tem-lhes um amor piedoso, 
um amor ausente: ternura para com o cadáver de uma amada morta a ser enterrada. Tristes velórios amargos esses em que se enterram amores. Depois de sentir o brasão português por entre os dedos e nas palmas das mãos recompôs-se e, ereto, decidido, pareceu empurrar com a mão direita a tapeçaria para dentro da parede, movendo-a ao redor de um eixo em seu centro. Segredos e passado. Brasões. Razões. Paixões.

Levou um tempo até que o mapa concluísse a volta de cento e oitenta graus, revelando seu outro lado, seu anverso, ou verso: versos. Um outro mapa-múndi surgira, diferente do que ali estivera até então. Nesta outra representação do mundo, não havia mais os verdes do pinhal de Leiria nem o ouro dos brasões portugueses. Via-se uma Europa inteira azul, As Américas vermelhas, a Ásia uma grande mancha amarela com remendos laranja. A África era púrpura e decorada com símbolos que indicavam regiões contaminadas por radiação. Diante do outro mapa, um jovem desapontado, volta novamente olhos para o chão e pergunta a si mesmo: por quê?

Camões e D. Sebastião pareciam prever a catarse que estava por vir. Confidenciavam receios, culpas, esperanças, dúvidas.

- Por quê? Repetia o jovem apoiado no balcão de mármore da lareira. De repente, com um golpe ferocíssimo desferido sobre o mármore, passou a vociferar na direção de Camões:

- Por que, seu caolho miserável? Por que nos fizeste acreditar tantos anos neste falso império? Nunca fomos nada e, tu, de repente, apareces descrevendo-nos como favoritos de deuses antigos, mitologias de papel, pergaminho e pó! Com que intento inventaste estas mentiras, estas ilusões?

Suas palavras tornavam-se mais ásperas e as lágrimas voltavam a escorrer-lhe dos olhos à medida que sua alteração crescia num ódio fulminante.

- Fizeste-nos crer por todos esses anos... Morremos às custas da tua história, perdemos tudo por acreditarmos na tua Ilha dos Amores! Onde estão agora as tuas ninfas. Esta - e aponta para o mapa na parede - é a Máquina do Mundo que nos estava reservada? É isto que estávamos fadados a vislumbrar? Verme! Mentiroso! O que pretendias, eu te pergunto, em nome dos teus deuses antigos, o quê?! Que espera que façamos agora? Já não somos sequer portugueses! Não há mais Portugal, o que há é essa maldita Europa! As veias da fronte e do pescoço do jovem português começavam a 
saltar-lhe à pele. A boca cuspia sem querer na face do escritor, as mãos agarravam-lhe o pescoço e se tivessem mais força decerto romperiam o bronze.

- Que maldita previsão fizeste? Melhor seria se tivessem dado ouvidos ao velho do restelo! Deste-nos o sonho para que pudéssemos permanecer perdidos para sempre no areal... Uma derrota atrás da outra; sempre um não! Sempre um quase! Sempre um nunca mais... O homem agora beirava o desespero e perda total de si mesmo, embora suas palavras parecessem ser ditas dentro do mais perfeito juízo.

- Mataste nosso rei! Jogaste-o na fogueira moura! Responde agora, cão, onde está D. Sebastião?! Que foi feito do rei que conduziste à guerra?! É a isto que ficou reduzido: a um busto de bronze? Tu, maldito caolho, destruíste teu próprio povo! Te importavas somente com o fogo que não queima...

Tomado da força sobrenatural que surge com o ódio, a revolta e a loucura, levanta sobre si, com um grito de esforço desumano, o busto do poeta humanista. Vira-o na direção da lareira e, refletindo o fogo que subia da lenha em brasa, aos prantos, grita histérico:

- Conhece tu agora o fogo que queima! O fogo que não cantaste! Deixa o povo que levaste à ruina! Abandona a alma portuguesa para sempre! Liberta-nos!!!

Com um urro ainda maior e mais pavoroso, joga às chamas o busto de Camões e se lança ao chão com o mesmo esforço. A respiração alterada, a dor nos braços, o rosto contraído e desfigurado em prantos. Arrasta-se pelo chão e levanta-se apoiando-se nas poltronas. Caminha desorientado e chega até as tapeçarias do outro lado da sala onde portugueses empalam mouros. Seu pranto aumenta. Oh, a mentira... Tudo isso é uma grande mentira! Diz entre soluços. Volta à poltrona de onde se levantara inicialmente e deixa-se cair inerte, ficando assim, em silêncio, dialogando com o fogo, observando Camões em brasa. Passa-se um tempo, minutos, horas, semanas, anos, e ele toma entre as mãos novamente o seu Pessoa. Agarra-se ao livro infantilmente e desata na loucura de quem ama perdidamente mas não pode viver esse amor.

- Vai, Pessoa, queima tu também ao fogo, porque já não há português que te ouça nem compreenda tuas mensagens... E coloca o livro gentilmente por sobre a lenha e ao lado de Camões, cujo rosto já se tornara enegrecido. Volta-se agora para o busto de D. Sebastião em passo pesado, lento. Na expressão, uma cumplicidade quase familiar, um rogo, um desabafo: - És tudo o que temos, majestade, és toda nossa esperança. 
Foi-se a ilusão, foram-se as terras, foi-se Portugal assim como tu também te foste no passado. És tudo o que nos resta...

Abraça-se à coluna e apoia a cabeça na testa de D. Sebastião. Pranteia toda sua alma em convulsão. Na lareira, as últimas páginas do Pessoa ardem e açoitam o rosto de Camões. 